\title{
Effect Land Use Ratio Index to Reduce Flooding: A Case of Jirak Sub-watershed in the Arau Watershed, Padang
}

\author{
Lusi Utama ${ }^{1}$, Amrizal $^{2}$, Isril Berd ${ }^{3}$, Zuherna $^{4}$ \\ \{lusi_utamaindo115@yahoo.co.id\} \\ Civil Engineering Doctoral Program at Andalas University, Indonesia ${ }^{1}$ \\ Department of Agriculture Andalas University, Indonesia ${ }^{2,3,4}$
}

\begin{abstract}
The flood may occur for both climatology and human action factors. The climatology factors can be in the form of land degradation, land-use changes, and population increase. The land-use changes can be identified when there is a conversion of the recharge area into a built area. When the population increases, space needed also enlarges. The Jirak located in the Arau watershed in Padang. In analyzing it, this study applied a descriptive quantitative method. The image used in the map is analyzed with Arcgis 10 to get a flood-prone map. The rainfall is calculated by using methods of Gumbel, and Log Pearson III, the debit is calculated by using rational. The difference discharge between these is $7.469 \mathrm{~m}^{3} / \mathrm{second}$. It is necessary to regulate the type and use of land to reduce flooding by $7.469 \mathrm{~m}^{3} / \mathrm{sec}$ with a housing index ratio of $24.68 \%$ and plantations of $43.39 \%$.
\end{abstract}

Keywords: flood, land use, DAS, discharge, ratio index

\section{Introduction}

In Indonesia, the flood is one of the problems which often occurs in the watershed (known as DAS). The flood can be defined as an overflowing of a large amount of water beyond its normal confines which creates damages. Generally, a flood occurs for natural or human action factors [8]. Some of these factors include land degradation, land-use changes, and population increase. The land-use changes [13] can be identified when there is a conversion of the recharge area into a built area. The conversion may happen because there is potency for a flood area to transform into an area of city development, industrial, economics, and settlements. Besides, when the population increases, space needed also enlarges.

Consequently, the surface flow increase and causes the flood. In the headwaters part of the DAS of Batang Arau, the water capacity area is around 174.30 hectares, covering conservation areas, protected forest, and private lands [5]. Meanwhile,[10] states that there are floods, droughts, lack of water and land (as the effect of population increase) found in Batang Arau DAS every month. Therefore, [12] the river flow of the Batang Arau River needs to be 
fixed due to siltation. It also needs to have vegetation to keep more water under the soil. Lastly, it needs to analyze the use of the land to prevent the flood.

Batang Arau DAS is positioned in the height of height $1.915 \mathrm{~m}$ above sea level, the area of water catch capacity is $174.30 \mathrm{~km}^{2}$, and the river length is $216.27 \mathrm{~km}$. [5] Based on the previous study, it is also found that the main factors of the flood are the sharp topography and the change of land use [9]. The availability of water in Batang Arau DAS, cannot meet the need of the DAS so that it must be supplied from other DAS. For example, to fulfill the need of water for PDAM in the area of Batang Arau DAS, [11] half of it is supplied from PDAM in the area of Batang Kuranji DAS and Batang Air Dingin DAS.

Besides, the lack of this water supply causes conflict with farmers since they need water for their field and with other societies who need water for their work. On the other hand, the water debit is excess in certain months. As the effect of this inefficient management, the excess water cannot be accommodated by the river and the flood occurs. The water excess and shortage is caused by the morphometric factor, which is due to population growth, more settlement is needed and it affects the chances of the use of land and the type of land cover [1]. The Jirak sub-watershed located in the Arau watershed always experiences flooding.

Recorded on September 10, 2017, flooding occurred as high as $30-50 \mathrm{~cm}$ and the same flood also occurred on September 26, 2018. The area is a densely populated Jondul Rawang, Lubuk Begalung, Pengambiran, Bypass housing complex. The biggest flooding occurred on November 2, 2018. It caused the flooding of a bridge in the Public Works Office of Padang City, which was still under construction. So far this area has never happened after 30 years of free flooding. This flood resulted in around 1,600 houses submerged in water. The goals of the study is (1) obtaining the debit quantity due to the area of land use, (2) analyzing the debit quantity due to rainfall (4 station rainfall: Batu Busuk, Gunung Nago, Ladang Padi and Simpang Alai), and (3) determine the index ratio area and type of land use.

The functions of the study is (1) for policymakers who requires to control the flood, this study contributes to control the space utilization in both protected and aquacultures areas, also as an input to utilization permit mechanism in flood-prone areas and to normalize the space utilization in flood-prone areas according to adequate licensing mechanism, and as a reference in preparing Peninjauan Kembali Rencana Tata Ruang Wilayah(Judicial Review of Regional Spatial Planning) in the respective regions, and (2) for practical aspect in managing sub DAS Jirak, this study helps to identify areas which have a flood vulnerability. If the cause of flood for the wrong of land use has been identified, the maintained land and the type of the land to prevent the flood can be determined.

\section{Theoretical framework}

The planned rainfall or return period is the maximum daily rain used to calculate the maximum of rainfall. To calculate this planned rainfall, the method as standardized by SNI is called the distribution method [6]. Normal distribution or normal curve is also known as Gauss. The formula used in a normal distribution is:

$X_{T}=\bar{X}+K_{T} \cdot S$

$K_{T}=\frac{X_{Y}-R}{5}$ 
Normal Log Distribution Method is included it logarithmic which represents a straight line equation. The equation for this method is:

$$
\begin{aligned}
& Y_{T}=\bar{Y}+K_{T} \cdot S \\
& K_{T}=\frac{Y_{T}-\bar{Y}}{s}
\end{aligned}
$$

Log-Pearson III Distribution Method is mostly used in hydrology analysis, especially in analyzing maximum and minimum data with an extreme grade. The equation for this method is:

$$
\log X t=\log \bar{X}+G * S t
$$

If the population is limited, this method can be used through this equation:

$$
\begin{gathered}
X=\bar{X}+S . K \\
K_{T}=\frac{Y_{T}-Y_{n}}{S_{n}}
\end{gathered}
$$

determine the debit use the rational method [7], [8]:

$\mathrm{Q}=0.278 \times \mathrm{C} \times \mathrm{I} \times \mathrm{A}$

which are:

$$
\begin{array}{ll}
\mathrm{C} & =\text { Run Off Coefficient } \\
\mathrm{I} & =\text { Maximum Intensity during concentration time }(\mathrm{mm} / \mathrm{hour}) \\
\mathrm{A} & =\text { area of flow }\left(\mathrm{km}^{2}\right) \\
\mathrm{Q} & =\text { Maximum debit/discharge }\left(\mathrm{m}^{3} / \mathrm{debt}\right)
\end{array}
$$

Rainfall Intensity Mononobe:

$$
t_{c}=\left(\frac{0,87 \times L^{2}}{1000 \times S}\right)^{0,385}
$$

tc $=$ time of consentration

$\mathrm{L}=$ Length of Jirak

$\mathrm{S}=$ Slope

$$
I=\frac{R}{24}\left(\frac{24}{t_{c}}\right)^{\frac{2}{3}}
$$

$\mathrm{I}=$ Rainfall Intensity ( $\mathrm{mm} /$ hour)

$\mathrm{R}=\operatorname{rainfall}(\mathrm{mm})$ 
DAS has specific characteristics relating to soil type, land use, topography, slope and length of the land. Some factors that define this hydrology system are land use, slope, and length of the land which are done by humans [3]. Therefore, vegetation takes a big role to overcome these humans' [7] intervention toward nature. The need for land increases whereas the availability of the land decreases. To overcome this, it is necessary to keep the land area for DAS so that the sustainability of water sources can be guaranteed [4].

\section{Research method}

The problem is identified by conducting surveys in the form of interviews with officials and residents, observing the area, getting information from mass media, related government departments (to get the data of rain and map of DAS), and getting information from Provincial BPS. Then, reviewing the literature that relates to the debit of the land use. In this phase, the data needs are rainfall from 2005-2017, map (image), figure 1. The rainfall is calculated with the mathematic method and the discharge is measured by using rational formula. From the measurement of the existed condition and the map use, the debit is calculated by using the rational formula: $\mathrm{Q}=0.278 \mathrm{C} \mathrm{I}$ A. Determine flood areas, using an earth map and ArcGIS 10 , flood-prone areas will be drawn.

\section{Result and discussion}

The amount of rainfall according to the average method from the 4 stations is $\mathrm{R}=169.327$ $\mathrm{mm}$. The time of concentration $=\mathrm{TC}=4.218$ hours. The amount of Rainfall Intensity with the Mononobe formula, $\mathrm{I}=22.487 \mathrm{~mm} /$ hour. Using the Rational method: $\mathrm{Q}=0.278 \times \mathrm{C} \times \mathrm{I} \times$ A. See the Figure 1 below.

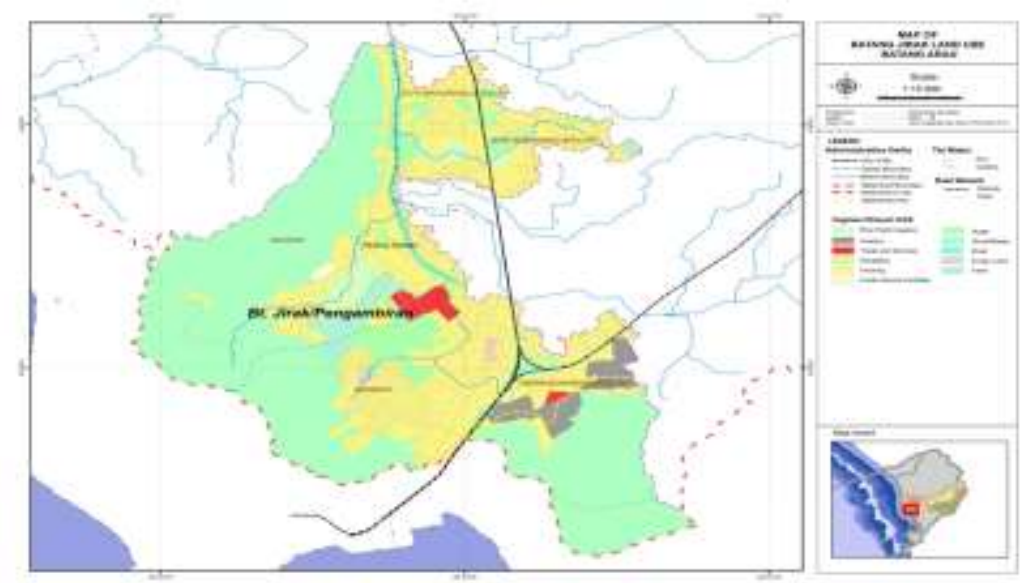

Fig. 1. Map of land use Jirak 
By using formula $\mathrm{Q}=0.278 \mathrm{C} \mathrm{I}$ A. Calculating the amount of debt that occurs as the effect of land use and land types in the sub-DAS Jirak as following Table 1 below.

Table 1. Discharge sub-DAS Jirak based on land use

\begin{tabular}{ccccc}
\hline Number & Vegetation & Area (A) Ha & Coefficient (C) & $\begin{array}{c}\text { Discharge }\left(\mathrm{m}^{3}\right. \\
\text { /second })\end{array}$ \\
\hline 1 & Industry & 17.42 & 0.6 & 0.653 \\
2 & Trade and Services & 7.10 & 0.5 & 0.222 \\
3 & Plantation & 3.28 & 0.15 & 0.031 \\
4 & Housing & 216.79 & 0.7 & 9.487 \\
5 & Public Sevice Facilities & 1.35 & 0.5 & 0.042 \\
6 & Rice Field Irrigation & 14.03 & 0.6 & 0.526 \\
7 & Barley & 45.49 & 0.3 & 0.853 \\
8 & River & 1.75 & 0.7 & 0.077 \\
9 & Empty Land & 2.04 & 0.2 & 0.026 \\
10 & Farm & 14.05 & 0.3 & 0.263 \\
& Total & 323.3 & & 12.180 \\
& Intensity & 22.487 & & \\
\hline
\end{tabular}

Used cylindrical rainfall measuring instruments with a diameter of $14 \mathrm{~cm}$. Area of Jirak Sub-watershed $=614.94 \mathrm{hm}^{2}=614.94$ ha. The average height of rainfall measured for 2 months $($ March $1-30$ April 2019 $)=2.3 \mathrm{~cm}$. Volume $=614.94 \times 2.3=1414.362 \mathrm{ha} \mathrm{cm}$. Rainfall is two hours $=7200$ seconds. Then Debit $=$ volume $/$ duration of rain $=1414.362$ ha $\mathrm{cm} / 7200$ seconds $=1414.362 \times 10000 \mathrm{~m}^{2} .0 .01 \mathrm{~m} / 7200$ seconds $=19.649 \mathrm{~m} 3 /$ second. There is a difference in discharge due to land use and rainfall $=19.649-12.18=7.469 \mathrm{~m} 3 / \mathrm{second}$. For this reason, changes in the area of housing and plantations are needed as follows in Table 2:

Table 2. Table determines the ratio index

\begin{tabular}{ccccc}
\hline Number & Vegetation & Area (A) Ha & $\begin{array}{c}\text { Coefficient } \\
(\mathrm{C})\end{array}$ & $\begin{array}{c}\text { Discharge }\left(\mathrm{m}^{3}\right. \\
\text { /second })\end{array}$ \\
\hline 1 & Industry & 17.42 & 0.6 & 0.653 \\
2 & Trade and Services & 7.10 & 0.5 & 0.222 \\
3 & Plantation & 140.28 & 0.15 & 1.315 \\
4 & Housing & 79.79 & 0.7 & 3.492 \\
5 & Public Sevice Facilities & 1.35 & 0.5 & 0.042 \\
6 & Rice Field Irrigation & 14.03 & 0.6 & 0.526 \\
7 & Barley & 45.49 & 0.3 & 0.853 \\
8 & River & 1.75 & 0.7 & 0.077 \\
9 & Empty Land & 2.04 & 0.2 & 0.026 \\
10 & Farm & 14.05 & 0.3 & 0.263 \\
& Total & 323.3 & & 7.469 \\
& Intensity & 22.487 & & \\
\hline
\end{tabular}

The index ratio for housing is: $79.79 / 323.3=24.68 \%$ and plantations $=140.28 / 323.3=$ $43.39 \%$ 


\section{Conclusion}

There is a very significant debit deviation occurs when the debit calculation is measured based on rainfall intensity, but ignoring the land use in each part of sub-DAS. Therefore, it is necessary to deliberate the land type and use that influence the debit. The debit for each subDAS based on the land use and type is $12.18 \mathrm{~m}^{3} / \mathrm{second}$, while the debit based on rainfall intensity is $19.649 \mathrm{~m}^{3} / \mathrm{second}$. The difference between these is $7.469 \mathrm{~m}^{3} / \mathrm{second}$. Due to higher land use debits, it is necessary to change the land use from the land to be built into green land. To reduce the floods, the ratio index for housing is $24.68 \%$ and plantations are $43.39 \%$. There are flood-prone areas, calculated by using Argis 10.

\section{References}

[1] Aprizon Putra., Analisis Bencana Banjir Kota Padang, Journal, (2013).

[2] Arikunto, Prosedur Penelitian. B. Aksara, Ed. Jakarta, (2006).

[3] Asdak, Hidrologi dan Pengelolaan DAS, Jogjakarta: Universitas Gajah Mada, (2002).

[4] Eze, E. B., \& Efiong, J., Morphometric Parameters of the Calabar River Basin: Implication for Hydrologic Processes, Journal of Geography, 2(1), 18-26 (2010).

[5] Hidayah Dwi Wahyu, Analisis Masalah DAS Batang Arau Kota Padang, Journal, (2012).

[6] Indarto, Dasar Teori dan Contoh Aplikasi Model Hidrologi, Jakarta: Bumi Aksara, (2014).

[7] Jaclyn M.H. Cockburn, John I. Garver, Abrupt change in the runoff on the north slope of the Catskill Mountains, NY, USA: Above average discharge in the last two decades, Department of Geography, University of Guelph, Guelph, ON, Canada Geology Department (2014).

[8] J. Musau, J. Sang, J. Gathenya E. Luedeling, Hydrological responses to climate change in Mt. Elgon watersheds, Biomechanical and Environmental EngineeringDepartment, Jomo Kenyatta University of Agriculture and Technology (JKUAT), KenyaWorld Agroforestry Centre (ICRAF), Gigiri, Nairobi, Kenya,(2014).

[9] Jun, M. J., Choi, K., Jeong, J. E., Kwon, K. H., \& Kim, H. J.,Landusecharacteristics of subway catchment areas and their influence on subway ridership in Seoul.Journal of Transport Geography, 48, 30-40. https://doi.org/10.1016/j.jtrangeo.2015.08.002, (2015).

[10]Kodoatie Robert J., Rekayasa dan Manajemen Banjir Kota, Jogjakarta, Andi Offset (2013).

[11] Lusi Utama, Kajian Morphometri pada DAS Batang Kuranjiterhadap Debit Banjir.(2017), Journal.

[12] Pune, Maharashtra, India.Shrikant M. Gabale, dan Nikhil R. Pawar,Departemen Geografi, Nowrosjeewadia Perguruan tinggi Analisa Ambilodha dalam Morphometric Kwantitatif, (2015).

[13]Stevanny Oktanthy Putri, Pengaruh Penggunaan Lahan terhadap Debit Aliran Sungai di Sub DAS Batang Arau, Journal (2011).

[14]Withanage, N. S., Dayawansa, N. D. K., \& Silva, R. P. De. Morphometric analysis of the Gal Oya river basin using spatial data derived from GIS.Tropical Agricultural Research, 26(1), 175188., (2014). 